\title{
Correlations among ratings of pain, disability and impairment in chronic whiplash-associated disorder
}

\author{
Howard Vernon DC FCCS
}

H Vernon.

Correlations among ratings of pain, disability and impairment in chronic whiplash-associated disorder.

Pain Res Manage 1997;4(2):207-213.

OBJECTIVE: To investigate the level of correlation among pain, disability and physical impairment scores in chronic whiplashassociated disorder patients.

SUBJECTS: Adults with chronic whiplash-associated disorder referred for secondary independent assessment.

METHODS: Forty-four subjects (16 males, 28 females) were included in the sample. Self-rated pain was measured on a five-point verbal rating scale. Self-rated disability was measured using the Neck Disability Index (NDI) and the Disability Rating Index (DRI). Physical impairment was measured as active cervical ranges of motion obtained with a cap goniometer. Descriptive statistics were reported and Pearson product moment correlations were obtained with the $P$ value at 0.01 .

RESULTS: Mean \pm SD age of the subjects was $36.4 \pm 8.7$ years. Mean duration of complaint was $15.2 \pm 12.3$ months. Mean pain score out of 5 was 2.5 \pm 1.2. Mean NDI and DRI scores were $23.2 \pm 9.3$ out of 50 and $21.6 \pm 9.1$ out of 48 , respectively. These scores correlated very highly $(\mathrm{r}=0.89, \mathrm{P}=0.0001)$. The average reduction of ranges of motion compared with published norms was approximately $25 \%$. The correlations among ranges of motion, NDI, DRI and pain scores ranged from -0.32 to $-0.66(\mathrm{P}<0.05$ to $\mathrm{P}=0.0001)$. Age and duration of complaint correlated poorly with ranges of motion. CONCLUSIONS: The self-ratings of pain and disability obtained from these chronic whiplash-associated disorder sufferers appear to be consistent with, and correlate reasonably well with, levels of physical impairment. Physical impairment ratings do not appear to correlate well with duration, which suggests that factors related to pain and physical impairment may play an important role in the development of chronicity in whiplash-associated disorder.

Key Words: Disability evaluation, Impairment, Neck pain, Questionnaires, Whiplash injuries

\section{Corrélations parmi les cotations de la douleur, de l'incapacité et de la déficience dans les troubles associés à l'entorse cervicale chronique}

OBJECTIF : Investiguer le niveau de corrélation parmi les scores de la douleur, de l'incapacité et de la déficience physique chez les patients accusant des troubles associés à l'entorse cervicale chronique.

SUJETS : Les adultes accusant des troubles associés à l'entorse cervicale chronique adressés pour une deuxième évaluation indépendante.

MÉTHODES : Quarante-quatre sujets (16 hommes, 28 femmes) ont été inclus dans l'échantillon. L'auto-évaluation de la douleur a été mesurée sur une échelle de cotation verbale de 5 points. L'auto-évaluation de l'incapacité a été mesurée à l'aide du Neck Disability Index (NDI) et du Disability Rating Index (DRI). La déficience physique a été mesurée comme amplitude des mouvements cervicaux actifs obtenus à l'aide d'un goniomètre. Les statistiques descriptives ont été rapportées et le coefficient de corrélation produit-moment de Pearson a été obtenu avec la valeur P à 0,01 .

RÉSULTATS : L'âge moyen \pm ET des sujets était de 36,4 $\pm 8,7$ ans. Les patients se plaignaient en moyenne depuis $15,2 \pm 12,3$ mois. Le score moyen de la douleur sur une échelle à 5 degrés était de $2,5 \pm 1,2$. Les scores moyens du NDI et du DRI étaient respectivement de 23,2 $\pm 9,3 / 50$ et de 21,6 $\pm 9,1 / 48$. Ces scores corrélaient fortement $(\mathrm{r}=0,89, \mathrm{P}=0,0001)$. La réduction moyenne de l'amplitude des mouvements comparée aux normes publiées était d'environ $25 \%$. Les corrélations parmi les amplitudes des mouvements, le NDI, le DRI et les scores de la douleur allaient de $-0,32$ à $-0,66(\mathrm{P}<0,05$ à $\mathrm{P}=0,0001)$. L'âge et la durée de la plainte des malades corrélaient peu avec les amplitudes des mouvements.

CONCLUSIONS : Les auto-évaluations de la douleur et de l'incapacité obtenues chez ces patients souffrant de troubles associés à l'entorse cervicale chronique semblent en accord avec les niveaux de déficience physique et corrèlent raisonnablement avec ces derniers. Par contre, les cotations de la déficience physique ne semblent pas bien corréler avec la durée, ce qui permet de croire que les facteurs liés à la douleur et la déficience physique joueraient un rôle dans le développement de la chronicité dans les troubles associés à l'entorse cervicale.

Canadian Memorial Chiropractic College, Toronto, Ontario

Correspondence and reprints: Dr H Vernon, Canadian Memorial Chiropractic College, 1900 Bayview Avenue, Toronto, Ontario M4G 3 E6.

Telephone 416-482-2340, fax 416-482-9745, e-mail hvernon@cmcc.ca

Received for publication August 6, 1997. Accepted October 27, 1997 
$\mathrm{M}$ orbidity due to 'whiplash-type' injuries resulting from motor vehicle accidents continues to plague Western society (1-12). While the reported incidence of whiplash-related insurance claims appears to vary widely (12), whiplash-associated injuries continue to account for huge health care and social costs. Recent benchmark reports by Spitzer et al (12) and Barnsley et al (1) have crystallized the current state of the art and have concluded that research into the whiplash phenomenon is sadly deficient.

The report by Spitzer and colleagues (12) particularly emphasizes the need for better means to assess whiplash-induced injuries. One of the challenges facing clinicians and researchers is the wide array of symptoms reported by whiplash-injured patients, which complicates diagnosis, classification and prognosis for this complaint. This situation prompted Spitzer et al to propose the term 'whiplash-associated disorder' to encompass the combination of somatic, psychological and social dysfunction associated with whiplash-type injuries.

In addition to their wide range of types and severity, these dysfunction symptoms have been reported to be very persistent $(2,3,5$, 7,11,13-21), leading Barnsley et al (1) to conclude that between $20 \%$ and $40 \%$ of whiplash-associated disorder sufferers will continue to report symptoms one year after injury, while at least $10 \%$ will have virtually permanent problems. On the other hand, Bovim et al (22) and Schrader et al (23) recently reported that the prevalence of 'late whiplash' symptoms was nearly identical to the level of neck pain reported in the general population.

While the scope of symptoms experienced by sufferers of whiplash-associated disorder is broad, relatively few attempts have been made to assess the impact of these symptoms on one's ability to engage in important activities of daily living. In reports on whiplashassociated disorder, symptom checklists are usually reported $(2,6,7$, $11,15,17,21,24)$, and data on occupational status have been used as a surrogate measure of recovery (12).

In 1991, Vernon and Mior (25) and Vernon (26) developed an instrument designed to assess the disability associated with neck pain, particularly arising from whiplash-induced injuries: the Neck Disability Index (NDI). This instrument was designed as a substantial modification of an existing, well-accepted measure for selfrating of disability due to low back pain (27). The original report, which included data on 48 subjects, $70 \%$ of whom had suffered a recent whiplash-induced neck injury, provided evidence of high testretest reliability (over a two day/no treatment interval), high internal consistency of the index's items, good concurrent validity with the McGill Pain Questionnaire (28) ( $\mathrm{r}=0.70)$ and good responsivity in a treatment setting.

Since 1991, several reports (reviewed in 26) and one replication study (29) have appeared, all supporting the NDI's psychometric properties. Hains et al (personal communication) found, first, that no order effect existed in either the items or the detractors; second, that one factor - physical disability - accounted for $69 \%$ of variance; third, that no item weighting was necessary; and fourth, that the correlations between pain scores and disability scores was 0.70 .

To the author's knowledge, no study exists in which a condition-specific instrument for measuring neck pain-related disability has been studied in relation to findings of pain and impairment in whiplash injured patients, particularly those whose conditions persist to become chronic. This kind of investigation is particularly im- portant regarding whiplash-injured patients because the usual approach to investigating their clinical status and course has been to employ symptom checklists and measures of psychosocial and/or cognitive dysfunction. Persistence of a variety of symptoms in various proportions of whiplash-associated disorder patients for 12 or more months has been reported $(2,6,7,11,15,17,21,24)$.

What has not yet been investigated in these patients is the degree to which pain and self-perceived disability ratings are associated with levels of physical impairment. This was the aim of the present study, which employed one measure of current self-rated pain intensity, two disability measures and the measurement of active cervical ranges of motion (AROM) in chronic whiplash sufferers referred for secondary assessment. In this study, the questions explored are: in a sample of chronic whiplash-associated disorder sufferers, is there a correlation between levels of self-reported pain and levels of selfreported disability?; and, is there a correlation between either or both of self-rated pain and disability levels and levels of objectively measured physical impairment? It was hypothesized that high correlations would be obtained between the two different disability measures (one condition-specific, the other generic [30]) and between these measures and the pain intensity rating. As well, it was hypothesized that there would be low correlations among range of motion measures (impairment), self-rated pain scores and self-rated disability measures, and moderate correlations between age and duration of complaint.

Finally, the possibility that two distinct subsets of items might exist in the NDI - symptoms and activities - prompted an exploratory analysis, with moderate correlations between these subsets predicted.

\section{PATIENTS AND METHODS}

This study involved an analysis of selected cases of chronic whiplash-injured patients living in a large metropolitan area. The case material was derived from examinations of these subjects conducted for the purpose of third-party payer assessments and by referral from these sources. All cases involved claimants who had suffered motor vehicle accident-related injuries and were continuing to receive ongoing therapy (mainly chiropractic treatment).

Subjects were examined by using a standardized protocol that included the following measures: demographic, clinical and accident-related data; a measure of self-rated current pain intensity (five-point verbal rating scale [28]); the NDI, a condition-specific instrument for self-rating of disability (25); the Disability Rating Index (DRI), a generic instrument for self-rating of disability that is a recently validated 12 -item measure of generic self-rated disability (30); and active ranges of cervical motion (see below).

Inclusion of cases in this study was based upon the following criteria.

1. Primary complaint of neck pain. Other symptoms such as headache and low back pain might have been present but were not the primary complaint.

2. Completion of at least one of the disability questionnaires. The primary reason for incompletion of this criterion was language difficulties.

Of 82 cases presenting from December 1994 to March 1996, 44 satisfied these inclusion criteria and form the case material of this 
report. Of those rejected for analysis, 21 were non-English speaking claimants who were unable to complete the disability questionnaires, 11 had a primary complaint of low back pain and six had incomplete files.

Data were extracted by a research assistant. The demographic, clinical and accident-related variables obtained from all files comprised sex, age, ethnic category, English as first or second language, duration of complaint, occupant status in the vehicle (driver, passenger or pedestrian) and mechanism of collision (rear, front or side).

All 44 claimants completed a single NDI (which included a sixpoint pain rating scale from 0 to 5), while 25 completed the DRI. All cases contained AROM measurements obtained from one trial in all six standard ranges for the neck using a cap goniometer $(31,32)$. AROM measurements were made in a consistent fashion, involving gentle manual guidance at the end range to stabilize the movement so that the maximum voluntary excursion could be measured accurately. No end range pressure was applied, so the subject's pain was solely that experienced from the active movement. AROM assessment has been used in several classic prognostic studies $(5,7,11)$ and in one recent prognostic study (15). Good intra- and interexaminer reliability has been reported for a magnetic goniometer (33-36) as well as for the cap-goniometer used in this study (31). In previous work within our group (unpublished data) interexaminer reliability coefficients obtained with this instrument ranged from 0.64 to 0.86 .

The data were analyzed descriptively and with Pearson product moment correlation coefficients with $\mathrm{P} \leq 0.01$. This alpha level was selected to avoid accepting spurious significance given the large number of correlations analyzed. Correlations were conducted between the two disability instruments, and between the conditionspecific disability instrument and each of age and duration of complaint. Correlations were also conducted between the range of motion data and both disability instruments, pain scores, age and duration of complaint.

Finally, an exploratory analysis was conducted by separating the NDI items into two categories: symptoms (items 1, 5, 6 and 9) and activities (items 2, 3, 4, 7, 8 and 10). Scores of these items were added to form one category score out of 20 for symptoms and out of 30 for activities. Each of these scores was then correlated with the range of motion data.

\section{RESULTS}

Demographic characteristics of the sample, presented in Table 1, show a predominance of Caucasian females in the third to fifth decades of life, with relatively lengthy durations of complaint postaccident. The majority of cases were drivers who were involved in rear-end collisions, although in about one-third of cases, a frontal collision precipitated the pain.

The mean \pm SD pain intensity score was $2.48 \pm 1.09$ out of 5 . The mean \pm SD of scores on the NDI and DRI are shown in Table 2. The correlation between the two instruments was $0.89, \mathrm{P}=0.0001$. Table 2 also displays correlation coefficients between NDI scores and age and duration of complaint, neither of which was significant.

Table 3 displays data on the AROM, including the mean \pm SD for each range as well the average reduction in AROM from published norms (37-39). AROM results from this study were compared with those obtained by Hagstrom and Carlsson (15) and with

\begin{tabular}{|c|c|}
\hline \multicolumn{2}{|c|}{$\begin{array}{l}\text { TABLE } 1 \\
\text { Demographic and accident-related data of the study } \\
\text { sample }\end{array}$} \\
\hline \multicolumn{2}{|l|}{ Sex } \\
\hline Female & $64 \%$ \\
\hline Male & $36 \%$ \\
\hline Age (mean $\pm \mathrm{SD})$ & $36.4 \pm 8.7$ years \\
\hline Duration of complaint (mean \pm SD) & $15.2 \pm 12.3$ months \\
\hline \multicolumn{2}{|l|}{ Collision type } \\
\hline Rear & $51 \%$ \\
\hline Front & $36 \%$ \\
\hline Side & $13 \%$ \\
\hline \multicolumn{2}{|l|}{ Occupant status } \\
\hline Driver & $75 \%$ \\
\hline Passenger & $23 \%$ \\
\hline Pedestrian & $2 \%$ \\
\hline
\end{tabular}

\section{TABLE 2 \\ Disability index scores and correlations}

\begin{tabular}{lc}
\hline Mean \pm SD NDI score (out of 50) & $23.2 \pm 9.3$ \\
Mean \pm SD DRI score (out of 48) & $21.6 \pm 9.1$ \\
Correlation between NDI and DRI & $r=0.89$ \\
& $(\mathrm{P}=0.001)$ \\
Correlation between NDI and age & $r=-0.22(\mathrm{NS})$ \\
$\begin{array}{c}\text { Correlation between NDI and duration of } \\
\text { complaint }\end{array}$ & $\mathrm{r}=0.17(\mathrm{NS})$
\end{tabular}

DRI Disability Rating Index; NDI Neck Disability Index; NS Not significant

TABLE 3

Active cervical ranges of motion (in degrees) obtained with cap goniometer

\begin{tabular}{lcc}
\hline Range & Mean \pm SD & \% normal \\
\hline Extension & $48.47 \pm 18.76$ & $69 \%$ \\
Flexion & $47.47 \pm 13.47$ & $79 \%$ \\
RLB & $36.72 \pm 12.37$ & $82 \%$ \\
LLB & $37.96 \pm 12.22$ & $84 \%$ \\
RRot & $48.09 \pm 17.71$ & $69 \%$ \\
LRot & $50.64 \pm 18.31$ & $72 \%$ \\
\hline
\end{tabular}

LLB Left lateral bend; LRot Left rotation; RLB Right lateral bend; RRot Right rotation

American Medical Association guides; results are outlined in Table 4. Correlations of the AROMs with the NDI, DRI and pain scores are displayed in Table 5. All correlations were moderately strong and were highly significant, although the correlations with NDI scores were slightly higher.

Table 6 displays the correlations between age and duration of 


\begin{tabular}{|c|c|c|c|c|}
\hline \multirow[b]{2}{*}{ Range } & \multirow{2}{*}{$\begin{array}{l}\text { Present } \\
\text { study }\end{array}$} & \multicolumn{2}{|c|}{$\begin{array}{l}\text { Hagstrom \& Carlsson } \\
\text { (reference 15) }\end{array}$} & \multirow{2}{*}{$\begin{array}{c}\text { AMA guides } \\
\text { (reference } 37 \text { ) }\end{array}$} \\
\hline & & Patients & Controls & \\
\hline Extension & $48 \pm 19$ & $49 \pm 22$ & $79 \pm 12$ & 60 \\
\hline Flexion & $47 \pm 13$ & $38 \pm 17$ & $60 \pm 9$ & 50 \\
\hline RLB & $37 \pm 12$ & $31 \pm 13$ & $45 \pm 6$ & 45 \\
\hline LLB & $38 \pm 12$ & & & \\
\hline RRot & $48 \pm 18$ & $51 \pm 15$ & $79 \pm 7$ & 80 \\
\hline LRot & $51 \pm 18$ & & & \\
\hline
\end{tabular}

TABLE 5

Correlations of active cervical ranges of motion with the NDI, DRI and pain scores

\begin{tabular}{|c|c|c|c|}
\hline Range & NDI & DRI & Pain score \\
\hline Extension & -0.58 & -0.54 & -0.51 \\
\hline Flexion & -0.58 & -0.52 & -0.59 \\
\hline RLB & -0.66 & -0.59 & $-0.35^{*}$ \\
\hline LLB & $-0.49 * *$ & $-0.32^{*}$ & $-0.34^{*}$ \\
\hline RRot & -0.63 & -0.54 & -0.53 \\
\hline LRot & -0.52 & $-0.45^{* *}$ & -0.53 \\
\hline
\end{tabular}

complaint and the ranges of motion. These were all generally low, with none being found significant at $\mathrm{P}=0.01$. Item analyses for the NDI, showing the ranking of the mean \pm SD for all 10 items, are compared with those from the author's original report (25) in Table 7. For the exploratory analyses, the average correlation coefficient for AROM/category 1 (symptoms) was 0.45 , while it was 0.61 for AROM/category 2 (activities). The two categories were moderately but significantly correlated $(\mathrm{r}=0.55, \mathrm{P} \leq 0.05)$.

\section{DISCUSSION}

The link among pain, impairment and disability is likely not symmetrical (40-50). This phenomenon has been studied much more extensively in low back pain patients than in those with neck pain. In the 1980s, several instruments were developed to assess functional disability relative to activities of daily living in low back pain sufferers including the Oswestry Low Back Pain Disability Questionnaire (OLBPDQ) (27), and the Roland-Morris Questionnaire (51). Others followed, including generic (as opposed to conditionspecific) instruments for measuring pain-related disability $(50,52-$ $55)$.

Investigators have used these instruments to assess the relationship among pain, impairment and disability in low back pain. Triano and Schultz (56) found that low back pain sufferers with
TABLE 6

Correlation of active cervical ranges of motion values with age and duration

\begin{tabular}{lcc}
\hline Range & Age & Duration of complaint \\
\hline Extension & -0.16 & 0.14 \\
Flexion & -0.19 & $0.35^{*}$ \\
RLB & $-0.32^{*}$ & 0.03 \\
LLB & $-0.29^{*}$ & 0.14 \\
RRot & -0.12 & 0.17 \\
LRot & -0.14 & 0.01 \\
\hline
\end{tabular}

All values were not significant except ${ }^{*} P \leq 0.05$. LLB Left lateral bend; $L$ Rot Left rotation; RLB Right lateral bend; RRot Right rotation

TABLE 7

Comparison of Neck Disability Index (NDI) item analysis with the author's original report (25)

\begin{tabular}{lcc}
\hline NDI items & Mean \pm SD & Rank in original 1991 study \\
\hline Headache & $2.91 \pm 1.44$ & 1 \\
Lifting & $2.67 \pm 1.42$ & 2 \\
Recreation & $2.63 \pm 1.29$ & 3 \\
Reading & $2.59 \pm 1.05$ & 4 \\
Pain intensity & $2.48 \pm 1.09$ & 6 \\
Work & $2.41 \pm 1.22$ & 7 \\
Sleeping & $2.37 \pm 1.42$ & 8 \\
Driving & $2.34 \pm 1.27$ & 5 \\
Concentration & $1.98 \pm 1.34$ & 10 \\
Personal care & $1.00 \pm 0.98$ & \\
\hline
\end{tabular}

OLBPDQ scores of 13 or higher out of 50 were much more likely to demonstrate paraspinal muscular dysfunction, as measured by electromyogram, and altered trunk active ranges of motion, particularly in forward flexion.

Waddell and Main (47) and Waddell et al $(48,57)$ reported that disability levels in low back pain sufferers correlated more highly with psychosocial measures of distress than with measures of pain severity.

Gronblad et al (58-62) reported relatively good correlations in chronic low back pain patients between disability scores, as measured by a condition-specific instrument, the OLBPDQ, and a generic instrument, the Pain Disability Index (63) ( $r=0.83$ ), and measures of impairment, particularly the performance of simple physical performance tests in the trunk ( $r=0.30$ to 0.41$)(62)$. Their most recent work, however, failed to demonstrate strong correlations between disability ratings and trunk AROM scores.

The investigation of this relationship is in its infancy regarding the assessment of disability in neck pain sufferers. In Norris and Watt's classic report (11), it is indicated that AROM measurements were obtained in their sample of 61 whiplash-associated disorder patients, but these values were not reported. Hildingsson and Toolanen $(6,7)$ reported on the persistence of reduced AROM at 25 months' follow-up in their sample of 93 motor vehicle accident 
sufferers, with between $11 \%$ and $24 \%$ showing signs of reduced AROM. These values were, unfortunately, not reported for the baseline status, nor were they correlated with any of the other variables in the study.

Weh et al (24) used functional x-ray analysis in flexion/extension to compare 105 whiplash-associated disorder cases after two years with age- and sex-matched controls. They reported significantly less total flexion/extension in the whiplash-associated disorder group and, particularly, reduced segmental motion in the upper cervical spine.

Osterbauer et al (64) employed an electrogoniometer in the assessment of 10 whiplash-associated disorder cases who were provided with chiropractic treatment. The pretreatment mean total AROM was $234^{\circ}$, which is considerably reduced from the norm of $360^{\circ}$ (2). After a six-week treatment program, the mean total AROM had increased to $297^{\circ}$, while pain scores had reduced from 44.1 to $10.5 / 100 \mathrm{~mm}$.

More recently, Hagstrom and Carlsson (15) measured pain, AROM and muscular tenderness in 30 cases of whiplash-associated disorder, comparing the results with those of 30 healthy controls. AROM values were significantly lower in the whiplash-associated disorder group, and AROM values correlated with pain (Visual Analogue Scale) scores in the whiplash-associated disorder group (Table 5). Our results compare very favourably with those of Hagstrom and Carlsson, with regard to both the average AROM values of chronic whiplash-associated disorder cases and to the correlation between pain ratings and AROM. Our study, however, also demonstrates a strong correlation between AROM and self-rated disability scores.

Similar to the whiplash-injured subjects in previous reports $(2,4,7,10,11)$, the subjects in the present report were predominantly female drivers injured in rear-end collisions with lengthy durations of complaint, making these subjects a group of typical chronic pain sufferers. However, because referral to this clinical service was, in the first place, dependent on the needs of third-party payers, this sample may be somewhat skewed in relation to the chronicity and lack of expected recovery, issues that would prompt a referral for independent assessment in the first place. In this type of subject, the prevailing clinical wisdom suggests that a poor link might exist between their impairment status and their self-perceived disability status $(47,48,57)$. As discussed below, our findings question this thinking.

The correlation observed in this study between the NDI and DRI is higher than the correlation of 0.38 reported by Salen et al (30) for the DRI and the OLBPDQ. Our much higher finding ( $r=0.89)$ may be interpreted as another confirmation of the construct validity of the NDI, in that it appears to measure the single factor of 'physical disability'. This finding suggests that researchers and clinicians can now choose between injury-specific or generic instruments in the assessment of disability due to chronic whiplash-induced injury.

The psychometric properties of the NDI were further explored here, with further evidence that age and now duration do not influence scores, and with evidence that the item rankings, as first reported by Vernon and Mior (25), are relatively stable, even in a population with more chronic pain. Additionally, a novel exploration has revealed only moderate levels of correlation between two subsets of items, which might be regarded as subfactors related to the primary factor of physical disability, namely symptoms and activities. This analysis suggests that these two subsets may offer unique information and that some subjects may endorse higher levels of symptom expression compared with activity reduction, and vice versa.

The average reduction in active range of motion compared with published norms $(2,4,39)$ was approximately $25 \%$, with extension and right rotation the ranges with the highest reduction $(31 \%)$. The reduction in extension is consistent with previous reports of the long term stiffness of the anterior cervical musculature $(2,8,10)$. The bilateral implication of this finding would be manifested in reduced extension (ie, reduced movement in the sagittal plane), while unilateral anterior myofascial stiffness would result in reduced rotation (ipsilateral) and lateral bending (contralateral).

Neither of the bilateral measures (rotation or side bending) demonstrated any significant side-to-side differences. This is consistent with data on neck range of motion testing in controls and sincere pain subjects (31-36). Taken together, however, the range of motion deficits observed in these subjects constitute only a moderately severe impairment level that is somewhat less than would be expected given the chronicity of these cases.

The degree to which current pain severity levels in chronic whiplash-associated disorder sufferers is associated with self-rated disability and objectively measured impairment is important because, as Radanov and Sturzenegger (17) and Radanov et al (18-20) have shown, there is a strong association among initial pain, injury severity ratings and the development of persistent symptoms (ie, chronicity). The correlations of pain and disability measures with impairment measures (AROM) found in this present sample are surprisingly high, with the highest correlations generally observed between AROM and the NDI scores. All correlations were in the expected negative direction given the nature of the data used for the analysis; ie, lower range of motion measures were reasonably wellcorrelated with higher self-rated pain and disability scores. Because NDI, DRI and pain scores are all reasonably well-correlated, the fact that the correlations between these scores and AROM were all in generally the same range ( 0.30 to 0.60$)$ is not surprising.

The lack of correlation between age and AROM is interesting given that AROM is known to reduce with advancing age $(38,39)$. However, the age range of our subjects was relatively small and confined to the third to fifth decades, which is before the age range when progressive degenerative disc disease becomes significant. As well, the progressive, age-related reductions in AROM are generally small and continuous, making it unlikely that age accounts for the reductions observed in this sample.

The lack of correlation between AROM and duration is somewhat surprising, in that chronicity may be associated with progressive increase in impairment. One possible explanation for this unexpected finding is that those whiplash-injured claimants who go on to experience chronic difficulties may reach a plateau of pain, impairment and self-rated disability, the complex of which remains approximately static from that time onwards. Because this was not a prospective study, this explanation remains to be confirmed in a longitudinal study. It is, however, consistent with the follow-up data reported in the literature $(2,6,7,11,15,17,21,24)$ on persistent symptomatology and cognitive difficulties in the minority of whiplashinjured cases that go on to become chronic. 
This study has several important limitations. While the selfreport measures were provided by the subjects themselves, and while all case data were extracted by a research assistant, the AROM values were obtained by the author in an unblinded fashion. Bias may have been introduced here. Future studies should employ an independent examiner for this or any other physical impairment measures. A case-control design that blinds the examiner as to subject status would be ideal.

Second, the study sample may have been skewed by factors related to the referral for assessment. Not all chronic whiplashassociated disorder cases are necessarily chosen for assessment referral. Factors acting to facilitate referral, such as case management issues, litigation status and dispute with the insurer, may have created a selection bias that then influenced the measures obtained in the study. However, study sample characteristics were similar to those of previously reported whiplash-associated disorder groups regarding sex, age, occupant status and collision type $(2,7,9,11$, 12,14). As well, the results of the analysis of NDI scores in this sample were quite similar to those presented in the first report (25) whose sample comprised $75 \%$ whiplash-associated disorder sufferers. Nonetheless, an ideal study would involve a prospective cohort assessed with these instruments on a serial basis in order to investigate the evolution of the condition and the extent to which similar correlations between the variables reported here might exist.

\section{REFERENCES}

1. Barnsley L, Lord S, Bogduk N. Whiplash injury. Pain 1994;58:284-307.

2. Croft AC. Soft tissue injury: long term and short term effects. In: Foreman SM, Croft AC, eds. Whiplash Injuries. London: Williams and Wilkins, 1988:271-327.

3. Deans GT, Magalliard JN, Kerr M, Rutherford WH. Neck sprain: a major cause of disability following car accidents. Injury 1987;18:10-2.

4. Dvorak J, Valach L, Schmid S. Cervical spine injuries in Switzerland. Man Med 1989;4:7-16.

5. Gore DR, Sepic SB, Gardner GM, Murray MP. Neck pain: a long-term follow-up of 205 patients. Spine 1987;12:1-5.

6. Hildingsson C, Toolanen G. Outcome after soft-tissue injury of the cervical spine: a prospective study of 93 car-accident victims. Acta Orthop Scand 1990;61:356-9.

7. Hildingsson C, Toolanen G. Outcome after soft-tissue injury of the cervical spine. Acta Orthop Scand 1990;61:357-9.

8. Hohl M. Soft tissue injuries of the neck in automobile accidents: factors influencing prognosis. J Bone Joint 1974;56A:1675-82.

9. Maimaris C, Barnes MR, Allen MJ. Whiplash injuries of the neck: a retrospective study. Injury 1988;19:393-6.

10. McNab I. The "whiplash syndrome". Orthop Clin North Am 1971;2:389-403.

11. Norris SH, Watt I. The prevalence of neck injuries resulting from rear-end collisions. J Bone Joint Surg Br 1983;65:608-11.

12. Spitzer WO, Skovron ML, Salmi LR, et al. Scientific monograph of the Quebec Task Force on Whiplash-Associated Disorders: redefining "whiplash" and its management. Spine 1995;20(Suppl 8):1S-73S.

13. Balla JI. The late whiplash syndrome. Aust NZ Med 1980;50:610-4.

14. Borchgrevink GE, Lereim I. Symptoms of patients with neck injury after a car crash. Tidsskr Nor Laegeforen 1992;112:884-6.

15. Hagstrom Y, Carlsson J. Prolonged functional impairments after whiplash injury. Scand J Rehab Med 1996;28:139-46.

16. Jonsson H, Cesarini K, Sahlstedt B, Rauschning W. Findings and outcome in whiplash-type neck distortions. Spine 1994;19:2733-43.

17. Radanov B, Sturzenegger M. The effect of accident mechanisms and initial findings on the long-term outcome of whiplash injury. J Musculoskel Pain 1996;4:47-60.

18. Radanov B, Begre S, Sturzenegger M, Augustiny KF. Course of psychological variables in whiplash injury: a 2-year follow-up with

\section{CONCLUSIONS}

A sample of chronic sufferers of whiplash-associated disorder has been investigated to explore the relationships among self-reported pain, disability scores and impairments as measured by reductions in AROM. Two instruments for measuring self-rated disability, one condition-specific and the other generic, correlated very well with each other and with pain scores. The correlations between these two measures and pain scores with AROM scores were moderately strong and highly statistically significant. AROM scores did not correlate well with age and duration of complaint, which suggests that chronicity in whiplash-associated disorder may be more directly linked to loss of physical function, and that whiplash-associated disorder sufferers may reach a plateau of reduced function and increased self-ratings of pain and disability, which then remain stationary. These findings also suggest that treatment interventions that target this link may be fruitful, either by directly increasing neck range of motion or by reducing self-ratings of pain and disability, particularly by focusing on attitudes and behaviours related to the avoidance of the very movements (57) that are actively restricted.

ACKNOWLEDGEMENTS: The author thanks Dr Cam McDermaid for thoughtful reviews and Bev Fuller for typing.

age, gender, and education pair-matched patients. Pain 1996;64:429-34.

19. Radanov BP, Sturzenegger M, De Stefano G, Schnidig A. Relationship between early somatic, radiological, cognitive and psychosocial findings and outcome during a one-year follow-up in 117 patients suffering from common whiplash. Br J Rheumatol 1994;33:442-8.

20. Radanov BP, Dvorak J, Valach L. Sequels of cervical sprain ("whiplash" injury). Man Med 1990;28:28-34.

21. Gargan MF, Bannister GC. The rate of recovery following whiplash injury. Eur Spine J 1994;3:162-4.

22. Bovim G, Schrader H, Sand T. Neck pain in the general population. Spine 1994;19:1307-9.

23. Schrader H, Obelienene D, Bovim G, et al. Natural evolution of late whiplash syndrome outside of the medicolegal context. Lancet 1996;347:1207-11.

24. Weh L, Bigdeli-Azari B, Dallmer J, Sablotny J. Persistent cervical dysfunction following whiplash injury. Man Med 1995;33:139-43.

25. Vernon H, Mior S. The Neck Disability Index: a study of reliability and validity. J Manipulative Physiol Ther 1991;14:409-15.

26. Vernon H. The Neck Disability Index: patient assessment and outcome monitoring in whiplash. J Musculoskel Pain 1996;4:95-100.

27. Fairbank JCT, Couper J, Davies JB, O'Brien JP. The Oswestry Low Back Pain Index. Physiotherapy 1980;66:271-3.

28. Melzack R. The McGill Pain Questionnaire: major properties and scoring methods. Pain 1975;1:275-99.

29. Leak AM, Cooper J, Dyer S, Williams KA, Turner-Stokes L, Frank AO. The Northwick Park Neck Pain Questionnaire: devised to measure neck pain and disability. Br J Rheumatol 1994;33:469-74.

30. Salen BA, Spangfort EV, Nygren AL, Nordemar R. The Disability Rating Index: An instrument for the assessment of disability in clinical settings. J Clin Epidemiol 1994;47:1423-34.

31. Zachman Z, Traina A, Keating JC, Bolles ST, Braum-Porter L. Interexaminer reliability and concurrent validity of two instruments for the measurement of cervical ranges of motion. J Manipulative Physiol Ther 1989;12:205-10.

32. Cassidy JD, Lopes AA, Yong-Hing K. The immediate effect of manipulation versus mobilization on pain and range of motion in the cervical spine: a randomized controlled trial. J Manipulative Physiol Ther 1992; 15:570-5.

33. Capuano-Pucci D, Rheault D, Aukai J, Bracke M, Day R, Pastrick M. 
Intratester and intertester reliability of the cervical range of motion device. Arch Phys Med Rehab 1991;72:338-40.

34. Rheault W, Albright B, Byers C, et al. Intertester reliability of the cervical range of motion device. J Orthop Sports Ther 1992;15:147-50.

35. Tucci SM, Hicks JE, Gross EG, Campbell W, Danoff J. Cervical motion assessment: a new, simple and accurate method. Arch Phys Med Rehab 1986;67:225-30.

36. Youdas JW, Carey JR, Garrett TR. Reliability of measurements of cervical range of motion: comparison of three methods. Phys Ther 1991;71:98-106.

37. American Medical Association. American Medical Association Guides to the Evaluation of Permanent Impairment, 4th edn. Chicago: AMA Press, 1993.

38. Dvorak J, Antinnes JA, Panjabi M, Loustalot D, Bonomo M. Age and gender related normal motion of the cervical spine. Spine 1992; 17:S393-8

39. Lind B, Sihlbom H, Nordwall A, Malchau H. Normal range of motion of the cervical spine. Arch Phys Med Rehab 1989;70:692-5.

40. Vasudevan S. Clinical perspectives on the relationship between pain and disability. Neurol Clin 1989;2:429-39.

41. Vasudevan SV. Role of functional capacity assessment in disability evaluation. J Back Musculoskel Rehab 1996;6:237-48.

42. Vasudevan SV. Assessment of disability status: the role of the physician. Wis Med J 1992;91:589-90.

43. Hazard RG, Haugh LD, Green PA, Jones PL. Chronic low back pain: the relationship between patients satisfaction and pain, impairment,and disability outcomes. Spine 1994;19:881-7.

44. Linton SJ. The relationship between activity and chronic pain. Pain 1985;21:289-94.

45. Pope MH, Rosen JC, Wilder DG, Frymoyer JW. The relation between biomechanical and psychological factors in patients with low back pain. Spine 1980;5:173-8.

46. Riley JF, Ahern DK, Follick MJ. Chronic pain and functional impairment: assessing beliefs about their relationship. Arch Phys Med Rehab 1988;69:579-82.

47. Waddell G, Main CJ. Assessment of severity in low-back disorders. Spine 1984;9:204-8.

48. Waddell G, McCulloch JA, Kummel E, Venner AM. Non-organic physical signs in low-back pain. Spine 1980;5:117-25.

49. Weinstein MR. The concept of the disability process. Psychosomatics 1978;19:94-7.

50. Rosomoff HL, Fishbain DA, Goldberg M, Santana R, Rosomoff RS. Physical findings with chronic intractable benign pain of the neck and/or back. Pain 1989;37:279-87.
51. Roland M, Morris R. A study of the natural history of back pain. Part I: Development of a reliable and sensitive measure of disability in low-back pain. Spine 1983;8:141-50.

52. Million R, Hall W, Nilsen H, Baker RD, Jayson MIV. Assessment of progress of back pain patients. Spine 1982;7:204-12.

53. Deyo RA. Measuring the functional status of patients with low back pain. Arch Phys Med Rehab 1988;69:1044-53.

54. Deyo RA, Diehl AK. Measuring physical and psychosocial function in patients with low back pain. Spine 1983;8:635-42.

55. Ruta DA, Garratt AM, Wardlaw D, Russell IR. Developing a valid and reliable measure of health outcome for patients with low back pain. Spine 1994;17:1887-96.

56. Triano JJ, Schultz AB. Correlation of objective measure of trunk motion and muscle function with low-back disability ratings. Spine 1987;12:561-5.

57. Waddell G, Newton M, Henderson I, Somerville D, Main C. A Fear-Avoidance Beliefs Questionnaire (FABQ) and the role of fear-avoidance beliefs in chronic low back pain and disability. Pain 1993;52:157-68.

58. Gronblad M, Lukinmaa A, Kontinnen Y. Chronic low-back pain: intercorrelation of repeated measures for pain and disability. Scand J Rehab Med 1990;22:73-7.

59. Gronblad M, Hupli M, Wennerstrand P, et al. Intercorrelation and test-retest reliability of the Pain Disability Index and the Oswestry Disability Questionnaire and their correlation with pain intensity in low back pain patients. Clin J Pain 1993;9:189-95.

60. Gronblad M, Jarvinen E, Hurri H, Hupli M, Karaharju EO. Relationship of the Pain Disability Index (PDI) and the Oswestry Disability Questionnaire (ODQ) with three dynamic physical tests in a group of patients with chronic low-back and leg pain. Clin J Pain 1994:10:197-203.

61. Gronblad M, Jarvinen E, Airaksinen O, Ruuskanen M, Hamalainen H, Kouri J. Relationship of subjective disability with pain intensity, pain duration, pain location and work-related factors in nonoperated patients with chronic low back pain. Clin J Pain 1996;12:194-200.

62. Gronblad M, Hurri H, Kouri J. Relationships between spinal mobility, physical performance tests, pain intensity and disability assessments in chronic low back pain patients. Scand J Rehab Med 1997;29:17-24.

63. Tait RC, Chibnall JT, Krause S. The Pain Disability Index: psychometric properties. Pain 1990;40:171-82.

64. Osterbauer PJ, Derickson KL, Peles JD, DeBoer KF, Fuhr AW, Winters JM. Three-dimensional head kinematics and clinical outcome of patients with neck injury treated with spinal manipulative therapy: a pilot study. J Manipulative Physiol Ther 1992;15:501-11. 


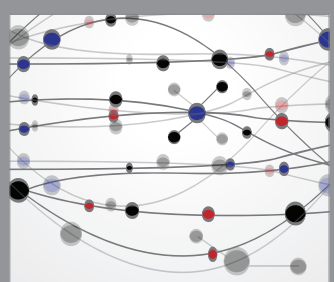

The Scientific World Journal
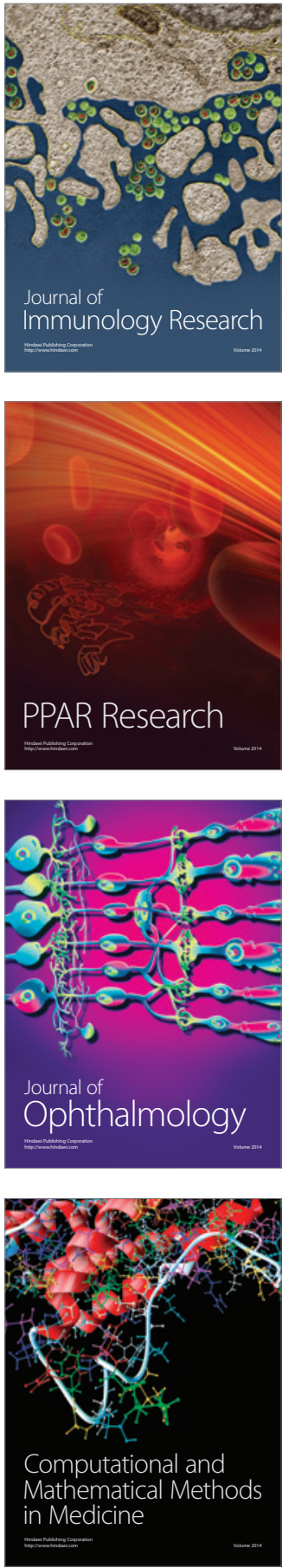

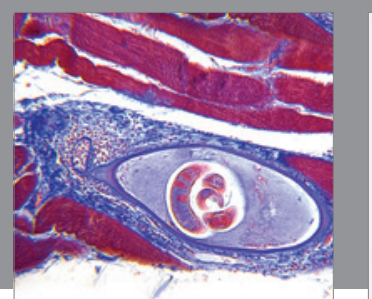

Gastroenterology Research and Practice

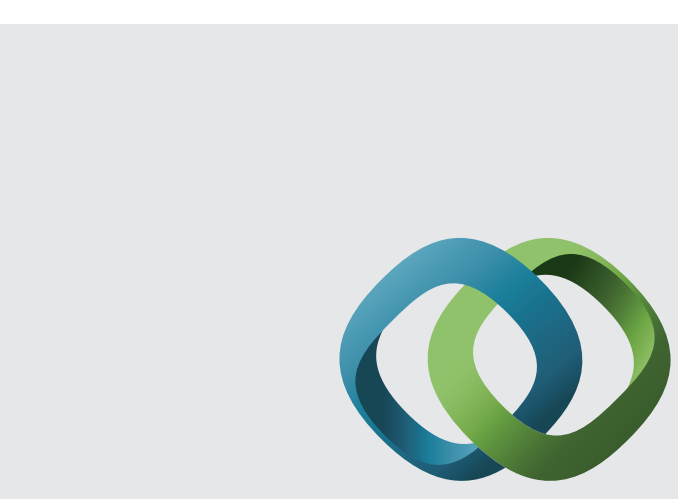

\section{Hindawi}

Submit your manuscripts at

http://www.hindawi.com
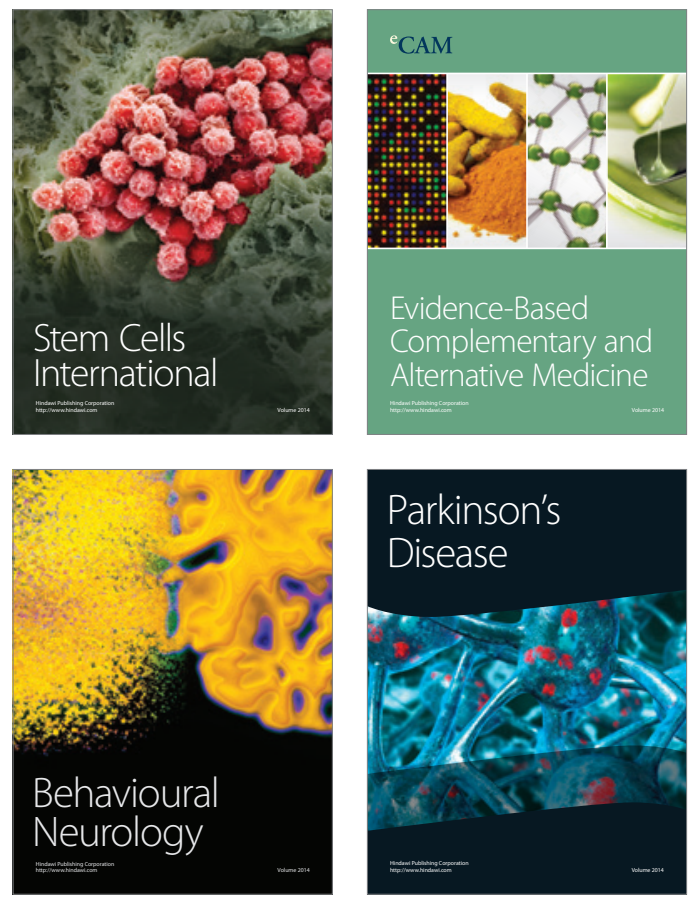
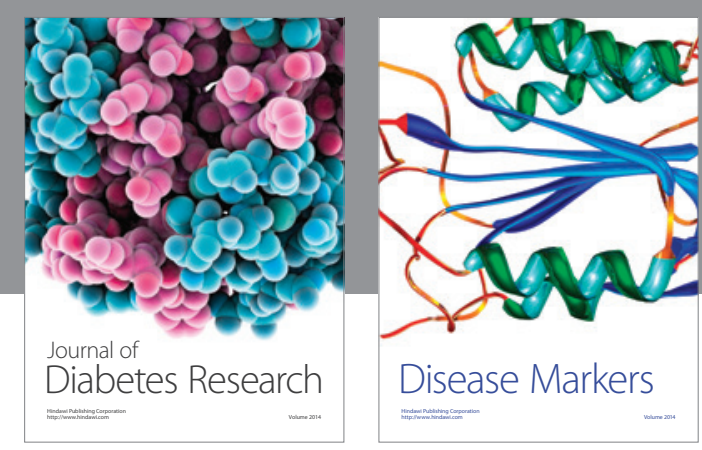

Disease Markers
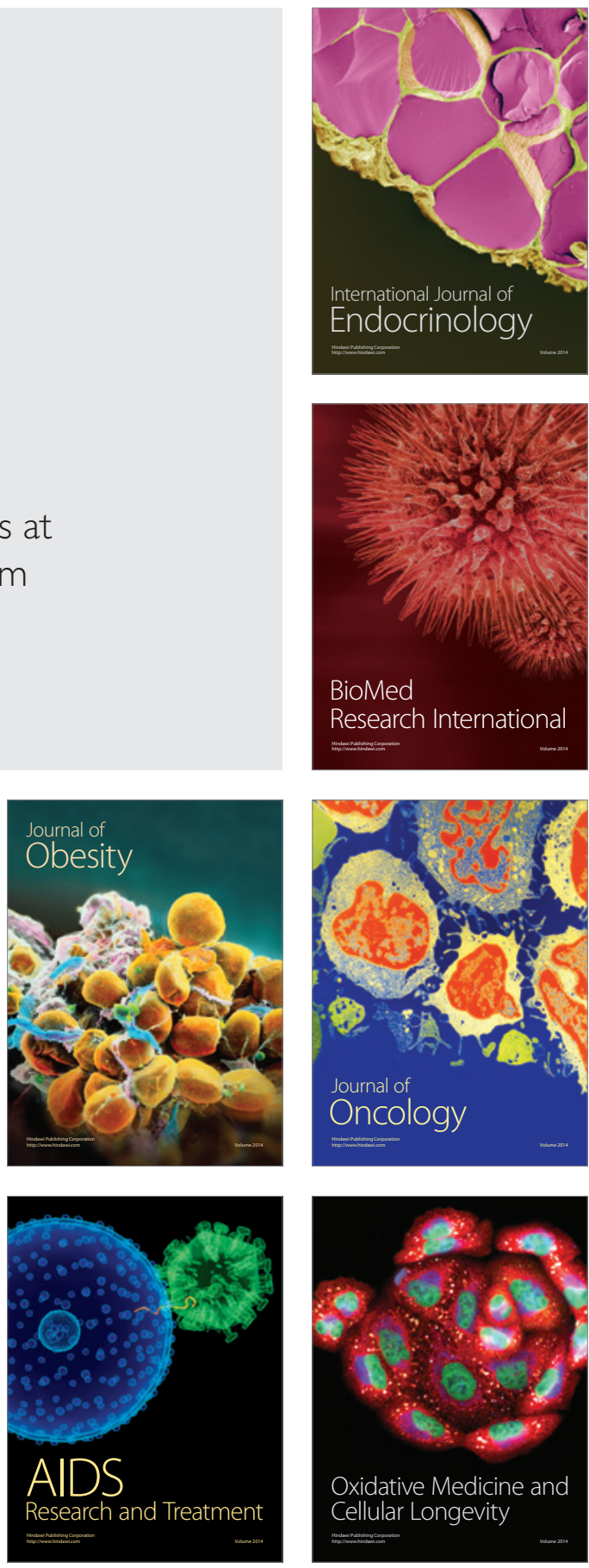